\title{
Pengaruh Penggunaan Material Daur Ulang Terhadap Sifat Mekanik Beton Non Pasir
}

\author{
Tommy Iduwin'; Dicki DP²; Pratiwi SP'; Hastanto $\mathrm{Sm}^{4}$ \\ 1, 2, 3, Program Studi Teknik Sipil, Institut Teknologi PLN \\ 'tommyiduwin@itpln.ac.id
}

\begin{abstract}
Infrastructure development is increasing every year making the need for concrete materials increases. Using alternative materials can reduce the scarcity of material and environmental damage caused by taking and dredging the material. This research is to find out how much influence the recycled material has on the compressive strength of no fines concrete. The variations used are recycled materials of $0 \%, 25 \%, 50 \%, 75 \%$ and $100 \%$. Mechanical testing conducted is a compressive strength test to determine the compressive strength of no fines concrete at the age of 7, 14 and 28 days. The ratio of cement and aggregate used is 1: 4 with FAS 0.5The test results show the highest compressive strength value of non-sand concrete occurs at $0 \%$ recycled material by $10.47 \mathrm{Mpa}$ and the lowest compressive strength on non-sand concrete $100 \%$ recycled material is $8.39 \mathrm{Mpa}$. The percentage of absorption of no fines concrete shows that the more recycled material is used, the smaller the value of water absorption. The highest absorption value in no fines concrete is $0 \%$ recycled material, which is $5.93 \%$ and the smallest value is in the variation of no fines concrete $100 \%$ recycled material recycled material that is equal to $4.99 \%$.
\end{abstract}

Keywords: No fines concrete, recycled material, compressive strength

\begin{abstract}
ABSTRAK
Pembangunan infrastruktur pada saat ini semakin meningkat dari tahun ketahun, sehingga memicu kebutuhan akan material beton semakin meningkat. Penggunaan material alternatif dapat mengurangi kelangkaan material dan kerusakan lingkungan yang disebabkan dari pengambilan dan pengerukan material. Penelitian ini dilakukan untuk mengetahui seberapa besar pengaruh material daur ulang terhadap kuat tekan pada beton non pasir. Penelitian ini menggunakan variasi material daur ulang 0\%, 25\%, 50\%, 75\% dan 100\%. Pengujian yang dilakukan adalah uji kuat tekan untuk mengetahui nilai kuat tekan beton non pasir pada umur 7, 14 dan 28 hari. Rasio semen dan agregat yang digunakan adalah 1:4 dengan FAS 0.5. Penelitian ini menggunkan cetakan silinder ukuran 15 x $30 \mathrm{~cm}$ sebanyak 45 benda uji. Hasil pengujian menunjukkan nilai kuat tekan beton non pasir tertinggi terjadi pada 0\% MDU sebesar 10.47 Mpa dan kuat tekan terendah pada Beton non pasir 100\% MDU sebesar 8,39 Mpa. Persentase penyerapan beton non pasir menunjukkan bahwa semakin banyak material daur ulang yang digunakan, maka semakin kecil nilai penyerapan airnya. Nilai penyerapan di umur 28 hari terbesar pada beton non pasir 0\% MDU yaitu 5,93\% dan yang terkecil di umur 28 hari terdapat pada variasi beton non pasir 100\% MDU material daur ulang yaitu sebesar $4,99 \%$.
\end{abstract}

Kata kunci: Beton non pasir, Agregat daur ulang, Kuat tekan 


\section{JURNAL FORUM MEKANIKA}

Vol. 9, No. 1, Mei 2020, P-ISSN: 2356-1491, E-ISSN: 2655-8211

DOI: https://doi.org/10.33322/forummekanika.v9i1.1080

\section{PENDAHULUAN}

Pembangunan infrastruktur pada saat ini semakin meningkat dari tahun ketahun, sehingga memicu kebutuhan akan material pembuat beton semakin meningkat pula. Dengan meningkatnya kebutuhan material ini akan berdampak berkurangnya jumlah sumber daya alam yang tersedia sehingga apabila dieksploitasi secara menerus sumber daya alam tersebut akan menimbulkan kelangkaan dan juga kerusakan lingkungan.

Penggunaan material alternatif dapat mengurangi kelangkaan material dan kerusakan lingkungan yang disebabkan dari pengambilan dan pengerukan material. Penggunaan material alternatif selain mengurangi kelangkaan dan kurasakan lingkungan juga dapat mengurangi biaya konstruksi.

Salah satu bahan alternatif yang bisa digunakan adalah pemanfaatan kembali agregat yang didaur ulang. Pemanfaatan agregat daur ulang ini akan mengurangi penggunaan sumber daya alam dan meminimalkan pembuangan limbah. Material daur ulang dapat berasal dari bongkaran bangunan tua karena bangunan tersebut perlu diperbaharui, bangunan yang mengalami kerusakan, bongkaran bangunan yang tidak layak huni, atau bangunan yang hancur akibat gempa. Sehingga limbah beton tersebut dapat dipergunakan untuk material alternatif yang bermanfaat.

Berdasarkan penelitian [1] yang melakukan penelitian tentang pengaruh limbah beton sebagai agregat kasar dan agregat halus terhadap kuat tekan beton normal. Hasil pengujian karakteristik limbah beton menunjukkan hasil yang hampir sama dengan agregat alam. Hasil pengujian benda uji dengan menggunakan limbah beton sebagai agregat kasar dan agregat halus menunjukkan terjadinya penurunan nilai kuat tekan dari kuat tekan beton rencana. Nilai kuat tekan beton rata-rata tertinggi pada umur 28 hari dari penggunaan limbah beton sebagai agregat kasar pada proporsi $60 \%$ dengan nilai kuat tekan 24,82 MPa, sedangkan dari penggunaan limbah beton sebagai agregat halus pada proporsi $80 \%$ dengan nilai kuat tekan 25,82 $\mathrm{MPa}$.

Beberapa hasil penelitian terdahulu menunjukan bahwa material daur ulang memiliki kualitas yang lebih rendah dibandingkan dengan agregat alami. Dengan kualitas yang dimiliki oleh material daur ulang tersebut sehingga lebih cocok digunakan untuk kebutuhan beton non struktural seperti beton non pasir [2].

Penelitian yang dilakukan [3] tentang beton non pasir dengan penggunaan agregat lokal. Penelitian ini dilakukan dengan membandingkan penggunaan semen agregat dengan perbandingan rasio semen agregat 1:4, 1:6, 1:8, 1:10. Hasil pengujian ini menunjukan bahwa penggunaan rasio semen agregat 1:6 memberikan nilai kuat tekan dan kuat lentur tertinggi yang masing-masing sebesar 3,712 MPa dan 0,963 N/mm2. Sedangkan untuk nilai daya serap air, nilai terbesar terdapat pada rasio semen agregat $1: 4$ sebesar $4,775 \%$. Proporsi optimum pada penelitian ini adalah rasio semen agregat $1: 6$.

Berdasarkan penelitian [4] yang melakukan penelitian tentang pengaruh penambahan fly ash terhadap sifat workability dan sifat fisik - mekanik beton non pasir dengan agregat alwa asal Cilacap. Penelitian ini dilakukan dengan penambahan porsi variabel fly ash sebesar 10-20\% dalam perbandingan perbandingan semen - agregat $1: 4 ; 1: 6 ; 1: 8$, dan nilai slump (nilai workability) yang diukur dan kekuatan tekan. Hasil penelitian menunjukkan penambahan fly ash mampu meningkatkan nilai slump hingga $7 \mathrm{~cm}$ dan mencapai $19,71 \mathrm{MPa}$ dari kuat tekan.

Penggunaan agregat daur ulang meningkatkan penyerapan air (sekitar 50\%); Namun, penurunan daya tahan terkait dapat dengan mudah dilawan dengan penggunaan campuran hidrofobik [5]. Struktur beton non pasir sangat berbeda dengan beton konvensional dalam pengertian bahwa pasta semen yang mengikat agregat menjadi satu berupa lapisan yang tipis. Ketika dilakukan 
pemadatan maka akan membuat partikel - partikel agregat menjadi lebih menyatu, sehingga pasta semen keluar dari bidang kontak dan menyelimuti partikel - partikel agregat tersebut [6].

Berdasarkan pertimbangan terhadap referensi yang digunakan maka penelitian yang akan dilakukan adalah meninjau beton non pasir yang merupakan salah satu jenis beton non struktural yang dapat diaplikasikan dalam pembangunan seperti dinding penahan tanah, rabat beton, sumur resapan dll. Dengan sifat beton non pasir yang dapat digunakan untuk bangunan non struktural sehingga beton non pasir tersebut cocok digunakan mengunakan material daur ulang. Melihat akan manfaat material daur ulang terhadap bahan susun material beton non pasir, maka perlu adanya pengetahuan dan inovasi dalam bidang kontruksi terus dikembangkan. Berdasarkan permasalahan tersebut di atas, maka penulis menilai perlu dilakukan penelitian dengan pengujian di laboratorium Pengaruh Reuse Material Terhadap Beton Non Pasir

\section{METODE/PERANCANGAN PENELITIAN}

Penelitian dilaksanakan di Laboratorium Beton Program Studi Teknik Sipil IT PLN Pelaksanaan penelitian ini berupa pemeriksaan material, perencanaan adukan beton, pengadukan material campuran beton, pengujian slump, pencetakan benda uji, perawatan benda uji, dan pengujian kuat tekan.

Tahapan dalam penelitian ini diawali dengan tahap studi literatur yaitu dalam tahap ini dilakukan pencarian referensi dan riset yang berhubungan dengan penelitian yang akan dilaksanakan.

Tahapan selanjutnya adalah persiapan bahat, alat dan pengujian material. Persiapan peralatan yang akan digunakan dan pengujian material utama, pembuatan yang akan dilaksanakan di Lab. Beton IT PLN.

Tahap selanjutnya adalah pelaksanaan berupa pembuatan sampel penelitian. Pembuatan sampel untuk penelitian ini sebanyak 45 sampel dengan variasi material daur ulang sebanyak $0 \%$, $25 \%, 50 \%, 75 \%$ dan 100\% dari jumlah agregat kasar. Pengujian sampel pada umur 7, 14, 28 hari, untuk mengetahui kekuatan tekan beton.

Tahapan selanjutnya adalah pelaksanaan pengujian dan pengumpulan data, tahap ini merupakan tahap melakukan pengujian tiap sampel yang sudah dibuat yang kemudian dicatat hasilnya. Selanjutnya adalah tahap Analisa data dan pembahasan. Setelah didapatkan data hasil pengujian kemudian dilakukan analisa dan pembahasan serta membandingkan untuk mengetahui nilai slump test, absorsi, kuat tekan beton. 


\section{JURNAL FORUM MEKANIKA}

Vol. 9, No. 1, Mei 2020, P-ISSN: 2356-1491, E-ISSN: 2655-8211

DOI: https://doi.org/10.33322/forummekanika.v9i1.1080
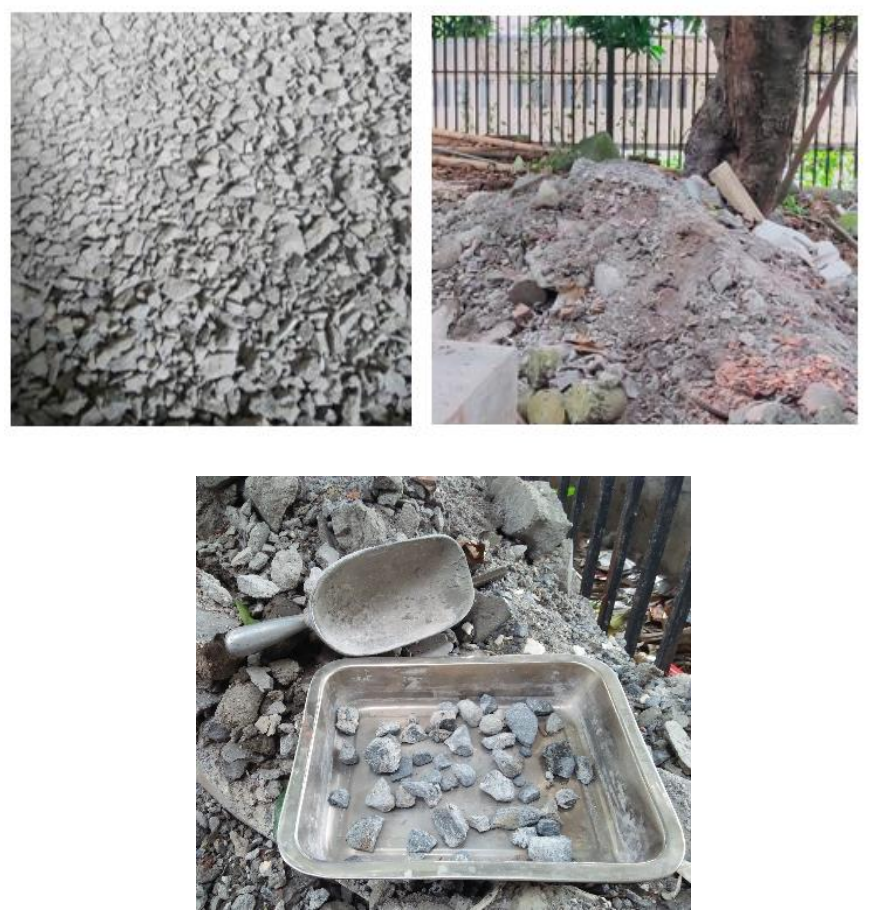

Gambar 1. Agregat Kasar MDU

\section{HASIL DAN PEMBAHASAN}

A. Pemeriksaan Bahan

Pemeriksaan bahan terdiri dari beberapa tahapan yaitu pemeriksaan semen dan agragat kasar. Pemeriksaan material dilakukan untuk mengetahui karakteristik sifat material yang digunakan. Pengujian fisis yang dilakukan pada penelitian ini adalah berat jenis dan penyerapan, gradasi agregat, kadar air, berat satuan, kadar lumpur dan loss angles. Selanjutnya juga dilakukan pemeriksaan karakteristik semen berupa berat jenis semen.

Tabel 1. Hasil Pengujian Karaktristik Material

\begin{tabular}{|c|l|c|c|}
\hline No. & \multicolumn{1}{|c|}{ Pengujian } & Nilai & Keterangan \\
\hline \multicolumn{2}{|c|}{ Agregat Kasar } & 7.07 & MHB \\
\hline 1 & Gradasi Agregat & 1.53 & $\%$ \\
\hline 2 & Kadar Air & 1396.17 & $\mathrm{Kg} / \mathrm{m} 3$ \\
\hline 3 & Berat Satuan & 2.46 & $\%$ \\
\hline 4 & BJ & 1.34 & $\%$ \\
\hline 5 & Penyerapan & 0.66 & $\%$ \\
\hline 6 & Kadar Lumpur & 20.44 & MHB \\
\hline 7 & LA & 7.1 & $\%$ \\
\hline Material Daur Ulang & 2.31 & $\%$ \\
\hline 1 & Gradasi Agregat & 2.3 & \\
\hline 2 & Berat Jenis & 37.76 & \\
\hline 3 & Penyerapan & 3.36 & \\
\hline 4 & LA & \multicolumn{1}{l|}{} \\
\hline Semen & Berat Jenis &
\end{tabular}




\section{B. Perencanaan Campuran Beton}

Perencanaan campuran beton pada penelitian ini berdasarkan berbandingan 1:4 antara air dan krikil. Pada table merupakan kebutuhan untuk masing-masing 9 benda uji silinder. Hasil perbandingan untuk campuran beton dapat dilihat pada Tabel 2.

Tabel 2. Proporsi bahan penyusun beton non pasir

\begin{tabular}{|c|c|c|c|c|}
\hline Varisai MDU & $\begin{array}{c}\text { Semen } \\
(\mathrm{kg})\end{array}$ & Krikil (kg) & $\begin{array}{c}\text { MDU } \\
(\mathrm{kg})\end{array}$ & Air (kg) \\
\hline $0 \%$ & 23 & 92.04 & 0 & 11.50 \\
\hline $25 \%$ & 23 & 69.03 & 23.01 & 11.50 \\
\hline $50 \%$ & 23 & 45.02 & 45.02 & 11.50 \\
\hline $75 \%$ & 23 & 23.01 & 69.03 & 11.50 \\
\hline $100 \%$ & 23 & 0 & 92.04 & 11.50 \\
\hline
\end{tabular}

Sumber : Hasil Analisis

\section{Pengujian Kuat Tekan}

Kekuatan tekan adalah kemampuan beton untuk menerima gaya tekan persatuan luas. Kuat tekan beton mengidentifikasikan mutu dari sebuah struktur. Semakin tinggi kekuatan struktur dikehendaki, semakin tinggi pula mutu beton yang dihasilkan.

Pengujian kuat tekan beton non pasir dilakukan menggunakan benda uji berbentuk silinder ukuran 15 x $30 \mathrm{~cm}$ yang telah diuji kuat tekan pada umur 7, 14 dan 28 hari. Berdasarkan nilai kuat tekan beton rata-rata yang terdapat pada Tabel 2 di atas, dapat disajikan dalam grafik yang terlihat seperti pada Gambar 2 dan Gambar 3 sebagai berikut :

Tabel 3. Hasil Rata-Rata Kuat Tekan Beton Semua Variasi

\begin{tabular}{|c|c|c|c|c|c|}
\hline $\begin{array}{c}\text { Umur } \\
\text { Pengujian }\end{array}$ & $\begin{array}{c}\text { Variasi } \\
0 \%\end{array}$ & $\begin{array}{c}\text { Variasi } \\
25 \%\end{array}$ & $\begin{array}{c}\text { Variasi } \\
50 \%\end{array}$ & Variasi 75\% & Variasi 100\% \\
\hline 7 & 9.24 & 8.77 & 8.30 & 8.02 & 7.73 \\
\hline 14 & 9.62 & 8.96 & 8.68 & 8.39 & 8.02 \\
\hline 28 & 10.47 & 9.24 & 9.05 & 8.68 & 8.39 \\
\hline
\end{tabular}

Sumber: Hasil Analisis 


\section{JURNAL FORUM MEKANIKA}

Vol. 9, No. 1, Mei 2020, P-ISSN: 2356-1491, E-ISSN: 2655-8211

DOI: https://doi.org/10.33322/forummekanika.v9i1.1080

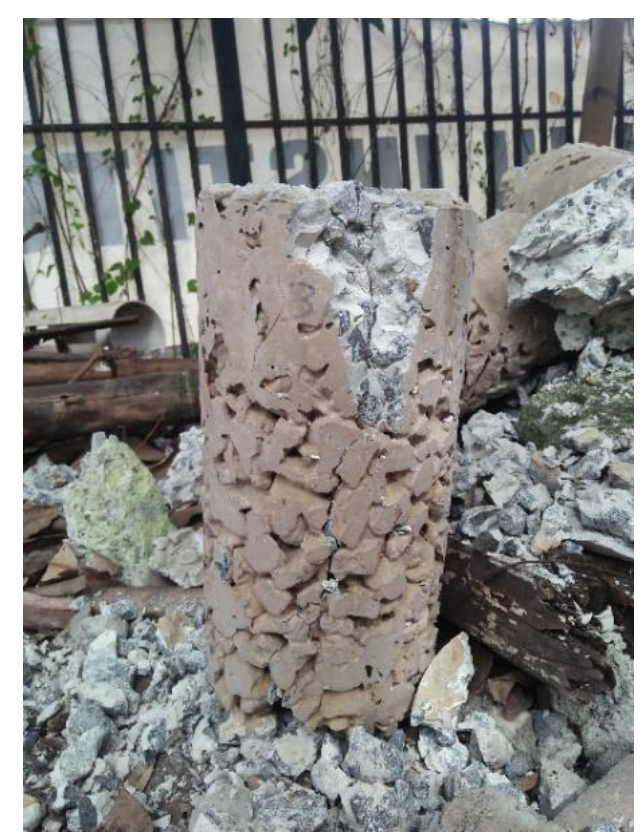

Gambar 2. Hasil pengujian beton non pasir

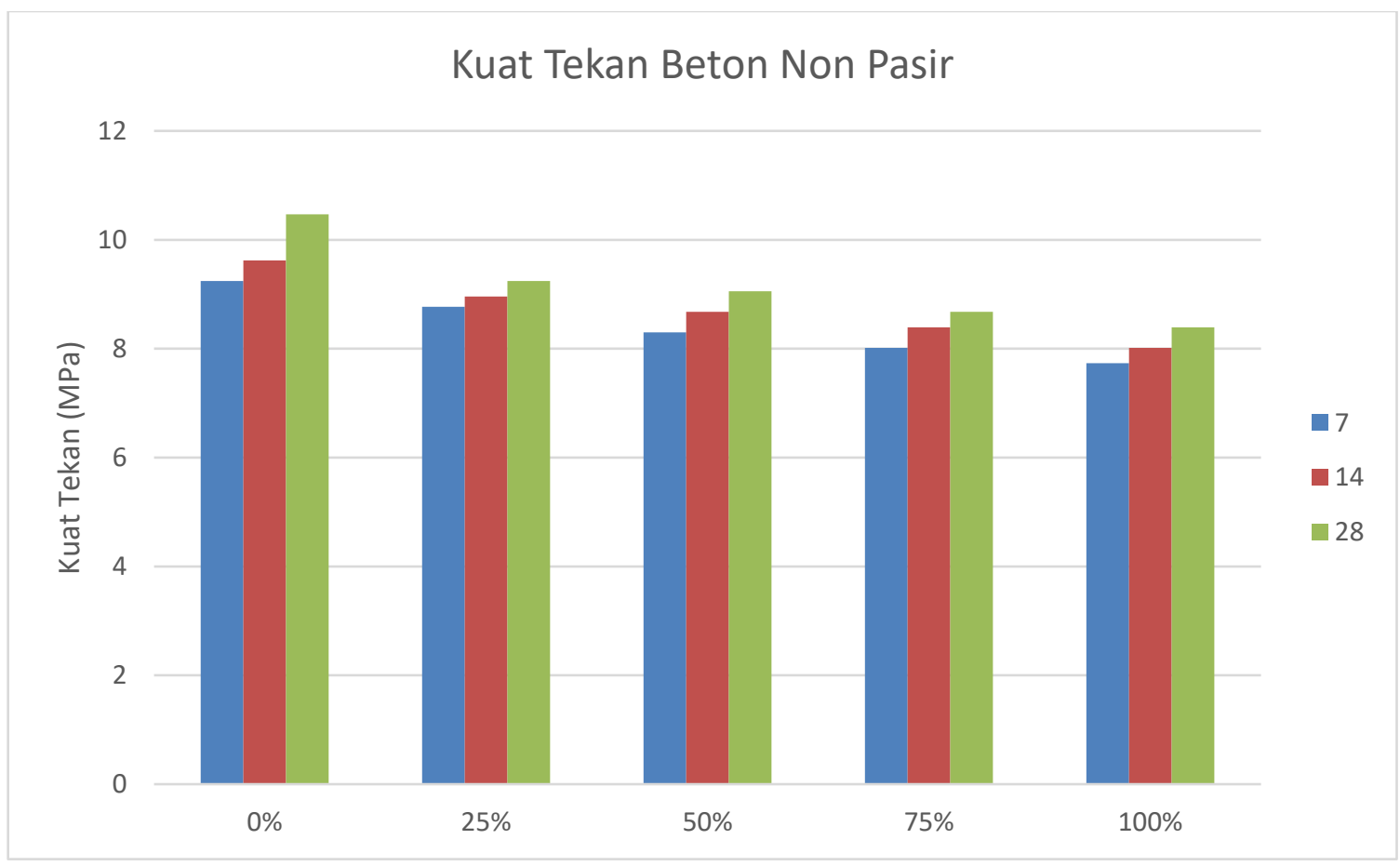

Gambar 3. Kuat Tekan Beton Non Pasir

Gambar 3 menunjukkan nilai kuat tekan rata-rata dari beton non pasir bahwa nilai kuat tekan tertinggi terjadi pada 0\% MDU yaitu sebesar 10.,47 Mpa. MDU 25\% memiliki kuat tekan rata-rata sebesar 9,24 Mpa. MDU 50\% memiliki kuat tekan rata-rata sebesar 9,05 Mpa. MDU 75\% memiliki kuat tekan rata-rata sebesar 8,68 Mpa. Kuat Tekan Terendah terjadi pada Beton non pasir 100\% MDU yaitu sebesar 8,39 Mpa. 
D. Penyerapan Beton

Setelah beton mengeras maka beton sudah siap untuk dilakukan pengujian absorbsi.

Pengujian absorbsi dilakukan pada saat umur beton 28. Adapun hasil pengujian penyerapan air disetiap variasi campuran dapat dilihat pada tabel dan grafik sebagai berikut :

Tabel 4. Hasil Uji Penyerapan

\begin{tabular}{|c|c|c|c|}
\hline Umur & Variasi & Penyerapan & $\begin{array}{c}\text { Rata Rata } \\
\text { Penyerapan } \\
(\%)\end{array}$ \\
\hline 28 & \multirow{3}{*}{ V1 } & 5.88 & \multirow{3}{*}{5.93} \\
\hline 28 & & 5.98 & \\
\hline 28 & & 5.93 & \\
\hline 28 & \multirow{3}{*}{ V2 } & 5.04 & \multirow{3}{*}{5.59} \\
\hline 28 & & 5.83 & \\
\hline 28 & & 5.88 & \\
\hline 28 & \multirow{3}{*}{ V3 } & 5.04 & \multirow{3}{*}{5.31} \\
\hline 28 & & 5.88 & \\
\hline 28 & & 5.00 & \\
\hline 28 & \multirow{3}{*}{ V4 } & 5.00 & \multirow{3}{*}{5.25} \\
\hline 28 & & 4.92 & \\
\hline 28 & & 5.83 & \\
\hline 28 & \multirow{3}{*}{ V5 } & 4.92 & \multirow{3}{*}{4.99} \\
\hline 28 & & 4.17 & \\
\hline 28 & & 5.88 & \\
\hline
\end{tabular}

Sumber: Hasil Analisis 


\section{JURNAL FORUM MEKANIKA}

Vol. 9, No. 1, Mei 2020, P-ISSN: 2356-1491, E-ISSN: 2655-8211

DOI: https://doi.org/10.33322/forummekanika.v9i1.1080

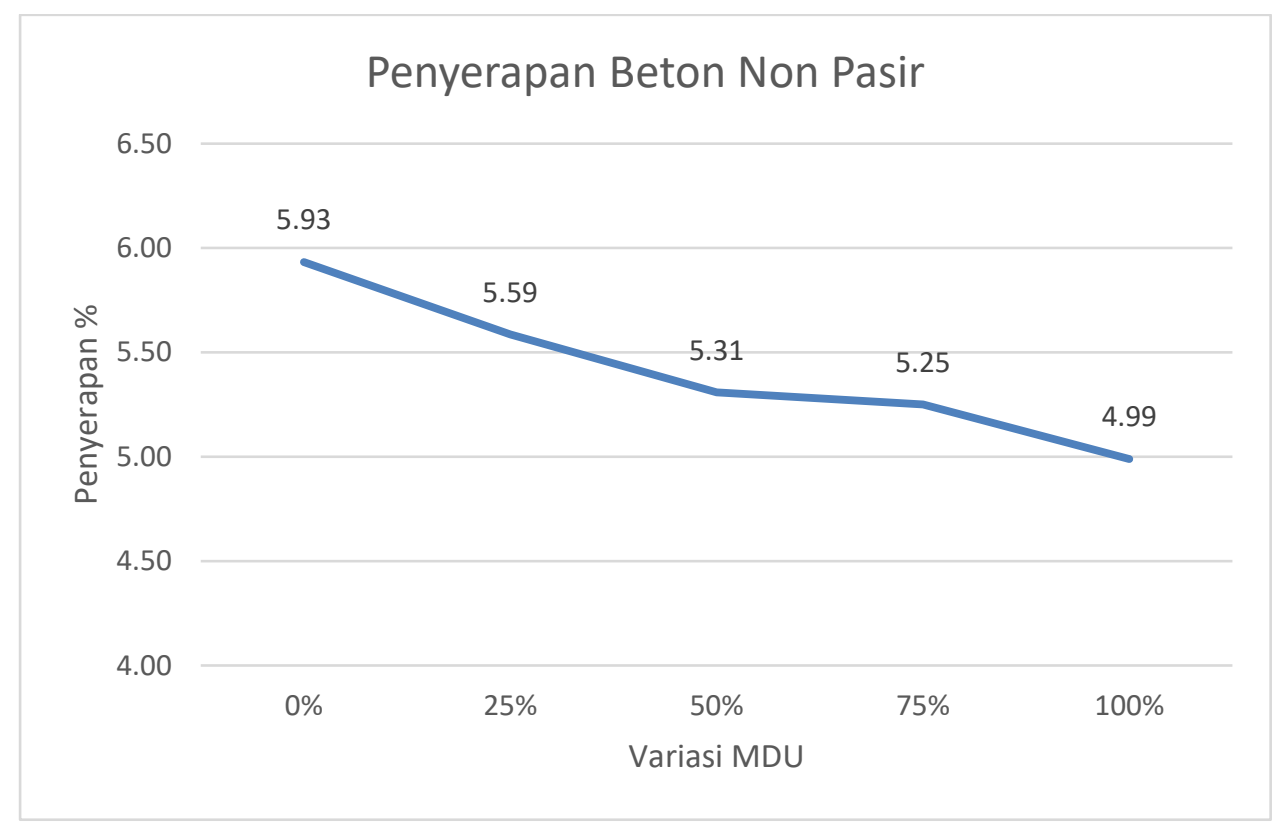

Gambar 4. Penyerapan Beton Non Pasir

Berdasarkan Gambar 4 persentase penyerapan beton non pasir dapat dilihat bahwa semakin banyak material daur ulang yang digunakan, maka semakin kecil nilai penyerapan airnya. Nilai penyerapan di umur 28 hari terbesar pada paving block normal yaitu 5,93\% dan yang terkecil di umur 28hari terdapat pada variasi beton non pasir $100 \%$ material daur ulang yaitu sebesar 4,99\%. Dari nilai kuat tekan dan nilai persentase penyerapan air beton non pasir yang telah diuji, maka variasi campuran maksimum terdapat pada campuran dengan variasi $0 \%$ material daur ulang dengan nilai kuat tekan 10,47 Mpa dan persentase penyerapan air pada umur 28 hari sebesar 5,93\%.

\section{KESIMPULAN DAN SARAN}

Berdasarkan hasil penelitian beton non pasir maka didapatkan kesimpulan nilai kuat tekan rata-rata dari beton non pasir menunjukkan bahwa nilai kuat tekan tertinggi terjadi pada $0 \%$ MDU yaitu sebesar 10.,47 Mpa. MDU 25\% memiliki kuat tekan rata-rata sebesar 9,24 Mpa. MDU 50\% memiliki kuat tekan rata-rata sebesar 9,05 Mpa. MDU 75\% memiliki kuat tekan rata-rata sebesar 8,68 Mpa. Kuat Tekan Terendah terjadi pada Beton non pasir 100\% MDU yaitu sebesar 8,39 Mpa. Persentase penyerapan beton non pasir menunjukkan bahwa semakin banyak material daur ulang yang digunakan, maka semakin kecil nilai penyerapan airnya. Nilai penyerapan di umur 28 hari terbesar pada beton non pasir normal yaitu 5,93\% dan yang terkecil di umur 28hari terdapat pada variasi beton non pasir $100 \%$ material daur ulang yaitu sebesar 4,99\%. Kualitas material daur ulang memiliki kualitas sesuai dengan standar SNI yang melalui pemeriksaan fisis (analisis saringan, berat jenis, absorbsi, dan loss angless). Hasil pengujian memenuhi fisis material daur ulang memenuhi standar SNI sehingga dapat digunakan sebagai campuran pembuatan beton non pasir. Beberapa saran terkait dengan hasil penelitian yang telah dilaksanakan adalah diharapkan agar material daur ulang dioptimalkan penggunaannya sebagai bahan alternatif dengan melakukan pengujian permabilitas karena memiliki tekstur yang berongga. perlu adanya percobaan menggunakan perbandingan semen dan agregat dengan tambahan perbandingan berbagai variasi. 


\section{UCAPAN TERIMAKASIH}

Penulis mengucapkan terima kasih kepada Prodi Teknik Sipil, LPPM IT-PLN dan tim penelitian yang telah memberi dukungan dan membantu pelaksanaan penelitian ini.

\section{DAFTAR PUSTAKA}

[1] A. A. Mulyati*, "PENGARUH PENGGUNAAN LIMBAH BETON Jurnal," J. Momentum ISSN 1693-752X, vol. 16, no. 2, 2014.

[2] E. Arifi, "Pemanfaatan Fly Ash sebagai Pengganti Semen Parsial untuk Meningkatkan Performa Beton Agregat Daur Ulang," Rekayasa Sipil, vol. 9, no. 3, pp. 229-235, 2015.

[3] Z. Darwis, B. Baehaki, and H. Supriyadi, "Beton Non-Pasir Dengan Penggunaan Agregat Lokal Dari Merak," J. Fondasi, vol. 6, no. 1, pp. 101-111, 2017.

[4] D. Trisnoyuwono, "Pengaruh Penambahan Fly Ash Terhadap Sifat Workability Dan Sifat Fisik - Mekanik Beton Non Pasir Dengan Agregat Alwa Asal Cilacap," J. Rekayasa Sipil, vol. 9, no. 1, pp. 29-36, 2015.

[5] F. Tittarelli, M. Carsana, and M. L. Ruello, "Effect of hydrophobic admixture and recycled aggregate on physical-mechanical properties and durability aspects of no-fines concrete," Constr. Build. Mater., vol. 66, pp. 30-37, 2014.

[6] P. . Harber, "Application of No-fines concrete as a Road Pavement," Rep. Univ., South. Queensl., no. October, pp. 1-130, 2005. 